\title{
In-silico Approach for The Prediction of Chlorogenic Acid as PPAR- $\gamma$ Activator
}

\author{
Yohanes Bare1, Mansur S'1, Sukarman Hadi Jaya Putra', Margaretha Rika W G L², Dewi Ratih Tirto \\ Sari $^{3}$ \\ ${ }^{1}$ Universitas Nusa Nipa, Maumere, east Nusa Tenggara, Indonesia \\ ${ }^{2}$ National Central University, Taoyuan, Taiwan \\ ${ }^{3}$ Universitas Brawijaya, Malang, Jawa Timur, Indonesia
}

Corresponding author: bareyohanes@gmail.com; mansursaputra00@gmail.com

\begin{abstract}
Coffee is one of the essential crops commonly cultivated in Indonesia. Coffee contains diverse bioactive compounds, which are associated with human health benefits. One of the compounds is Chlorogenic acid, which able to decrease the risk of type 2 diabetes mellitus (T2DM). However, the mechanism of chlorogenic acid toward anti-diabetes still unclear. This study aimed to analyze and investigate the potential role of chlorogenic acid as anti-diabetes through their interaction with Peroxisome proliferator-activated receptor gamma (PPAR- $\gamma$ ) as an enzyme to phosphorylate and regulate the mechanism of T2DM. The physicochemical properties of chlorogenic acid also performed in this study. The PPAR- $\gamma$ was downloaded from the PDB database, and the chlorogenic acid was retrieved from the PubChem database. The protein and ligand were prepared using the PyRx program and were docked using Hex 8.0.0 software. Discovery Studio client 4.1 software was used to analyze the interaction between chlorogenic acid and PPAR- $\gamma$ protein. Based on the physicochemical properties, chlorogenic acid is highly permeable to the cell and easily absorbed. Thirteen amino acid residues of PPAR- $\gamma$ (GLN410, SER394, ASP396, GLY395, GLU407, LEUA401, LEU400, VAL403, LYS373, LYS438, LEU377, LYS434, and GLY437) were identified on the chlorogenic acid-PPAR- $\gamma$ interaction. Interestingly, the kind of interactions, including hydrophobic interaction, hydrogen bond, and van der Waals, which are supported by the tight interaction. Our study indicated that chlorogenic acid might have anti-diabetes activity through PPAR- $\gamma$ interaction.
\end{abstract}

Keywords: anti-diabetes; chlorogenic acid; type 2 diabetes mellitus; in silico; PPAR- $\gamma$

\section{Introduction}

The prevalence of Type 2 diabetes mellitus (T2DM) in Indonesia in 2030 will increase to $7.8 \%$ (International Diabetes Federation, 2015). T2DM is a metabolic disease caused by an unhealthy lifestyle characterized by insulin resistance. In T2DM showed the diverse proteins which correlated with the healthy patient, Bare et al., (2018) found totals of protein in a normal condition more than in T2DM condition and lead some of the function of protein interleukin-10. One gene that has a relationship with T2DM is Peroxisome proliferator-activated receptor gamma (PPAR- $\gamma$ ). The PPAR$\gamma$ gene has an expression in regulating glucose homeostasis based on certain tissue needs. The PPAR- $\gamma$ gene functions to suppress insulin resistance by suppressing TNF- $\alpha$ performance in adiposity. Besides, PPAR- $\gamma$ also increases the expression of several genes that encode proteins involved in glucose and lipid metabolism (Kubota et al., 2006; Tyagi et al., 2011). The use of synthetic drugs to cure T2DM patients often causes several side effects, so patients are suggested to take combinational oral medicine to 
maximize the healing chance (Chaudhury et al., 2017). Some of the research try to find using natural ingredients from the local community to overcome this issue. The use of natural properties could reduce toxicity through structural modification (Kesuma et al., 2018).

Coffee is one of the most popular cultivation plants in Indonesia, especially in East Nusa Tenggara Province. Based on the Indonesian Bureau of Statistics in 2019, there is an increase in coffee production in East Nusa Tenggara Province from 20042017 with the 5 largest production districts starting from East Manggarai, Ende, Manggarai, Southwest Sumba and West Manggarai (Indonesian Bureau of Statistics, 2019). The increment of coffee production coffee correlates with the increase in coffee consumption in this province. Nowadays, coffee consumption not only to the taste and texture of drinks but also related to being a healthy lifestyle. Coffee has benefits for human health because coffee contains a variety of biologically active compounds such as caffeine and chlorogenic acid (Caprioli et al., 2014; Laukalēja \& Krūma, 2018; Nuhu, 2014). Chlorogenic acid is a group of phenolic compounds and found in Robusta green coffee (Adriana, 2012). Chlorogenic acid has been demonstrated both in vitro and in vivo for human health, namely as an antioxidant, anticancer (Farah \& Donangelo, 2006; Nuhu, 2014), antiviral B hepatitis, antihypertensive (Bare et al., 2019), anti-diabetic, hepatoprotective (Farhaty, 2016), anti-inflammation (Bare et al., 2019) and antispasmodic (Farah \& Donangelo, 2006).

Coffee has potential as anti-diabetic through the content of caffeine compounds. Ong et al. (2013) reported that consumption of chlorogenic acid could reduce the risk of $\mathrm{T} 2 \mathrm{DM}$ because it has anti-diabetic properties. The content of chlorogenic acid compounds in coffee beans has a pharmacological effect on the part of thiazolidinediones (TZDs), which has a treatment benefit that has been used by humans (Bermu'dez et al., 2010). The potential possessed by the chlorogenic acid further study as an anti-diabetic. This is the basis for new research in assessing the function of chlorogenic acid as a PPAR- $\gamma$ activator.

\section{Material and Method}

\subsection{Protein and Ligand Preparation}

The Protein Data Bank (PDB) was used to obtain the 3D structure of PPAR- $\gamma$ (PDB ID: 3cwd) in humans, SDF format acquired from http://www.rcsb.org. Protein 3D structure of PPAR- $\gamma$ from the database was eliminated other binding proteins and water molecules using the open babel tool in PyRx virtual screening software. The chemical structure of chlorogenic acid was taken from the PubChem.com database (CID: 1794427). Chlorogenic acid was minimized energy by an open babel tool in PyRx virtual screening software. Chlorogenic acid was converted into PDB format using PyRx virtual screening software. The molecular interaction process (Molecular Docking) used HEX 8.0.0 molecular docking software. 
Chlorogenic acid was predicted for its physicochemical properties, such as molecular weight (MW), the logarithm of the coefficient of octanol/water (Log P), the number of rotating bonds between atoms (Torsion); Hydrogen Bond Acceptors (HBA), Hydrogen Bond Donors (HBD), and Polar Surface Activity (PSA) is carried out using the pKCSM online tool (Kesuma et al., 2018)

\subsection{Molecular Docking}

PPAR- $\gamma$ protein was docked with chlorogenic acid. The docking used Hex 8.0.0 software. Molecular interactions between PPAR- $\gamma$ Protein and chlorogenic acid were visualized and analyzed using Discovery Studio software client 4.1 (Bare et al., 2019). The analysis included hydrogen bond, Van der Waals, amino acid residues, and energy formed by ligand (Tiring et al., 2019).

\section{Results and Discussion}

\subsection{Results}

The physicochemical properties Chlorogenic acid as a natural compound material have easy absorption and have high permeability (Table 1). The properties determined based on the World Drugs Index baseline, according to Lipinski et al. (1997).

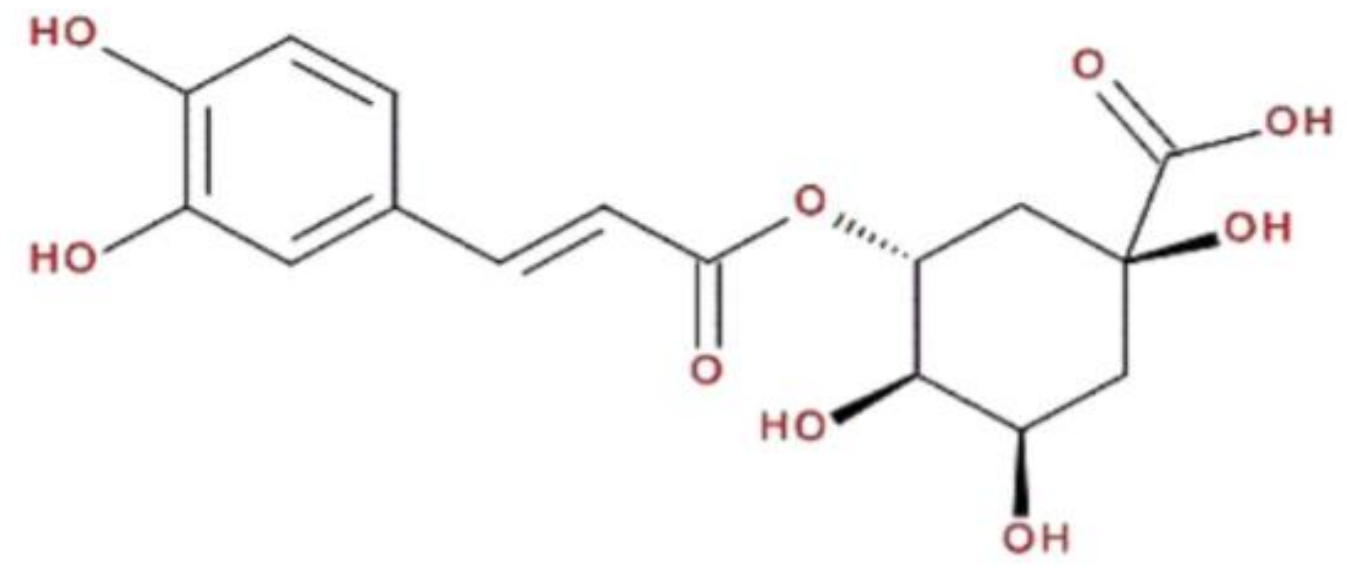

Figure 1. Chemical Structure Chlorogenic Acid (Hall et al., 2015)

This is confirmed by the molecular weight of chlorogenic acid 354.311 smaller than 500. The molecular weight of more than 500 caused the chemical compound is difficult to absorb by the amino acid (Lipinski et al., 1997). The value of the log coefficient of octanol/water ( $\log$ P) -0.6459 smaller than 5, the donor H-bond (HBD) $6>5$, and H-receptor (HBA) under 8. Table 1 shows that chlorogenic acid compounds required with The Lipinski's rule of five and can be used for in-sillico analysis. 
Table 1. The physicochemical properties of chlorogenic acid compounds used the pkCSM online tool.

\begin{tabular}{cccccccc}
\hline $\begin{array}{c}\text { Chemical } \\
\text { Compound }\end{array}$ & MW & LogP & Torsion & HBA & HBD & PSA (A2) & $\begin{array}{c}\text { Lipinski Legal } \\
\text { Requirements }\end{array}$ \\
\hline $\begin{array}{c}\text { Chlorogenic } \\
\text { Acid }\end{array}$ & 354,311 & -0.6459 & 4 & 8 & 6 & 141.587 & Yes \\
\hline
\end{tabular}

MW= Molecular Weight; $\mathbf{L o g} \mathbf{P}=$ logarithm of octanol/water partition coefficient; $\mathbf{T}$ Torsion $=\mathrm{a}$ bond between atoms that can rotate; HBA= Hydrogen Bond Acceptors; HBD= Hydrogen Bond Donors; PSA= Polar Surface Activity

We found an interaction on hydrophobic at amino acid residue VAL403. Other bonds formed from ligand and protein interactions are hydrogen bonds between protein ligands that interacted with amino acid residues LYS438, ASP396, and LYS343 types Conventional Hydrogen Bond (Table 2). The small distance formed by the hydrogen bond and amino acid residue from PPAR- $\gamma$ will be made the hydrogen bond stronger. Other function the bond caused interaction between chlorogenic acid and PPAR- $\gamma$ protein bond is more stable. Xu D, Tsai, \& Nussinov (1997) reported the smaller distance of hydrogen to the acceptor leads the hydrogen bond will be more durable (Santoso \& Atmajaya, 2016). Besides that, we found Van der Waals in amino acid residue LEU401, LYS373, LEU377, GLN437, GLN410, SER394, and GLU407.

Chlorogenic acid, which docked with Peroxisome proliferator-activated receptor gamma protein (PPAR- $\gamma$ ), showed an interaction between ligand-protein (Figure 2). Interestingly, interactions ligand-protein formed 13 amino acid residues with a variety of chemical bonds (Table 2). Thirteen amino acid residues found were GLN410, SER394, ASP396, GLY395, GLU407, LEUA401, LEU400, VAL403, LYS373, LYS438, LEU377, LYS434, and GLY437. Insulin resistance characterizes patients with type 2 diabetes mellitus (T2DM), leads to a buildup of blood sugar (hyperglycemia) in the human's body. Hyperglycemia causes tissue damage (oxidative stress) and the amount of protein lost in organ T2DM (Bare et al., 2018). Chlorogenic acid was predicted to have pharmacological therapy to suppress insulin resistance to improve insulin sensibility in cells. 
Table 2. Interaction Chlorogenic Acid and Peroxisome proliferator-activated receptor gamma (PPAR- $\gamma$ ) protein

\begin{tabular}{|c|c|c|c|c|c|c|c|}
\hline Complexes & $\begin{array}{c}\text { Energy } \\
\text { (cal/mol) }\end{array}$ & Name & Distance & Category & Types & $\begin{array}{c}\text { from } \\
\text { chemistry }\end{array}$ & $\begin{array}{c}\text { to } \\
\text { chemistry }\end{array}$ \\
\hline \multirow{8}{*}{$\begin{array}{l}\text { Chlorogenic } \\
\text { acid-PPAR- } \\
\gamma\end{array}$} & \multirow{8}{*}{$-267,6$} & $\begin{array}{l}\text { B:LYS438: } \\
\text { HZ1-: LIG1:0 }\end{array}$ & 2,26112 & $\begin{array}{l}\text { Hydrogen } \\
\text { Bond }\end{array}$ & $\begin{array}{l}\text { Conventional } \\
\text { Hydrogen } \\
\text { Bond }\end{array}$ & H-Donor & $\begin{array}{l}\text { H- } \\
\text { Acceptor }\end{array}$ \\
\hline & & $\begin{array}{l}\text { B:LYS438: } \\
\text { HZ3-: LIG1:0 }\end{array}$ & 2,66883 & $\begin{array}{l}\text { Hydrogen } \\
\text { Bond }\end{array}$ & $\begin{array}{l}\text { Conventional } \\
\text { Hydrogen } \\
\text { Bond }\end{array}$ & H-Donor & $\begin{array}{l}\text { H- } \\
\text { Acceptor }\end{array}$ \\
\hline & & $\begin{array}{l}\text { :LIG1: } \quad \text { H } \\
\text { A:ASP396: } \\
\text { OD2 }\end{array}$ & 2,53273 & $\begin{array}{l}\text { Hydrogen } \\
\text { Bond }\end{array}$ & $\begin{array}{l}\text { Conventional } \\
\text { Hydrogen } \\
\text { Bond }\end{array}$ & H-Donor & $\begin{array}{l}\text { H- } \\
\text { Acceptor }\end{array}$ \\
\hline & & $\begin{array}{l}\text { :LIG1: H - B: } \\
\text { LYS434:O }\end{array}$ & 2,4837 & $\begin{array}{l}\text { Hydrogen } \\
\text { Bond }\end{array}$ & $\begin{array}{l}\text { Conventional } \\
\text { Hydrogen } \\
\text { Bond }\end{array}$ & H-Donor & $\begin{array}{l}\text { H- } \\
\text { Acceptor }\end{array}$ \\
\hline & & $\begin{array}{l}\text { :LIG1: H - A: } \\
\text { LEU400:0 }\end{array}$ & 2,82748 & $\begin{array}{l}\text { Hydrogen } \\
\text { Bond }\end{array}$ & $\begin{array}{l}\text { Conventional } \\
\text { Hydrogen } \\
\text { Bond }\end{array}$ & H-Donor & $\begin{array}{l}\text { H- } \\
\text { Acceptor }\end{array}$ \\
\hline & & $\begin{array}{l}\text { A:VAL403:CG1 } \\
\text { - :LIG1 } \\
\text { A:VAL403:CG2 }\end{array}$ & 3,69406 & Hydrophobic & Pi-Sigma & $\mathrm{C}-\mathrm{H}$ & Pi-Orbitals \\
\hline & & - :LIG1 & 2,91755 & Hydrophobic & $\begin{array}{l}\text { Pi-Sigma } \\
\text { Unfavorable }\end{array}$ & $\mathrm{C}-\mathrm{H}$ & Pi-Orbitals \\
\hline & & $\begin{array}{l}\text { A:GLY395: HN } \\
\text { - :LIG1: H }\end{array}$ & 1,82234 & Unfavorable & $\begin{array}{l}\text { Donor- } \\
\text { Donor }\end{array}$ & H-Donor & H-Donor \\
\hline
\end{tabular}

a.

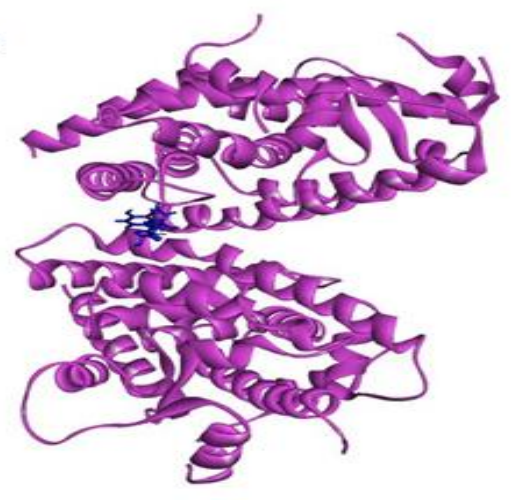

c.

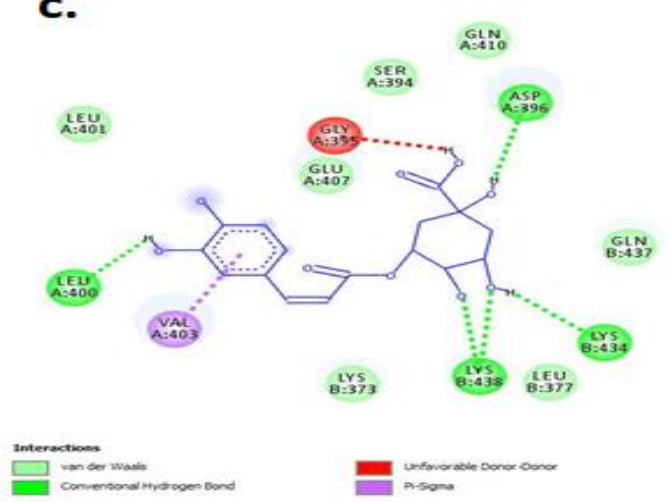

b.

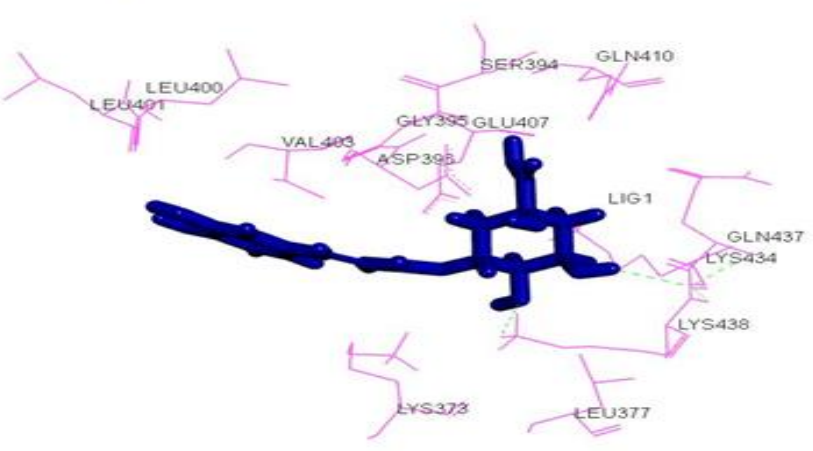

d.

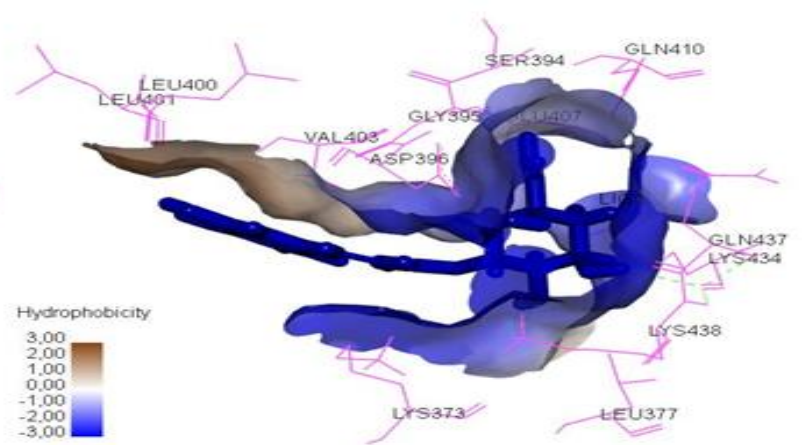

Figure 2. Molecular interaction between Chlorogenic Acid and Peroxixme proliferator-activated gamma receptor (PPAR- $\gamma$ ). a. Ligand and Protein interactions, b. 3D structure interaction, c. 2D structure interaction, d. Hydrophobicity complex. 


\subsection{Discussion}

Chlorogenic acid has isomer with a few subgroups that are caffeoylquinic acid (CQA), caffeoylquinic acid (CQA), feruloyl quinic acid (FQA), and p-coma-roylquinic acid (p-CQA) with the smaller totals. Chlorogenic acid also has three from 9 main isomers are CQA (3-,4- and 5-CQAs), three isomers from CQAs (3,4-,3,5-, and 4,5diCQAs) and three isomers in FQAs (3-,4-, and 5-FQA) (Farah \& Donangelo, 2006; Farhaty, 2016; Kreicbergs, 2011; Zanin et al., 2016). Roasted coffee of Coffee arabica contains 1.7to3.5g/100g chlorogenic acid content (Farah \& dePaula Lima, 2019). Chlorogenic acid has a function as anti-diabetic by in vivo and in vitro analysis (Farhaty, 2016).

The interaction between chlorogenic acid with the PPAR- $\gamma$ confirms that this compound potential as anti-diabetic role by the finding of thirteen amino acid residues that bind chlorogenic acid (figure 2 and table 2). Ligand interaction between Chlorogenic Acid and Peroxisome proliferator-activated receptor gamma protein (PPAR- $\gamma$ ) has an energy of $-267.6 \mathrm{cal} / \mathrm{mol}$ (Table 2). Chlorogenic acid will decrease T2DM by regulates the gene phosphorylation cascade as stimulating PPAR $-\gamma$. The protein encoded by the PPAR $-\gamma$ gene is found to be involved in lipid and glucose metabolism and is part of cell differentiation (Greenfield \& Chisholm, 2004). Chlorogenic acid also reported to works on PPAR- $\gamma$ to increase insulin tissue sensibility in muscle peripheral tissues (Aleshin et al., 2013; Bermu'dez et al., 2010; Geetha et al., 2018). Insulin sensitivity in muscle tissue influence on glucose transport in the blood and reduce excess sugar inside and outside the cell. Insulin has responsible the circulation at the level of the microvasculature in muscle and fat cells. To keep glucose homeostasis, insulin stimulates GLUT4 translocation and glucose uptake. GLUT4 translocation takes place of insulin binding to its receptors at the surface of myocytes and adipocytes (Tokarz et al., 2018). PPAR- $\gamma$ stimulation in the pancreas increases insulin secretion in the liver and reduces hepatic glucose production by inhibiting gluconeogenesis due to repression of phosphoenolpyruvate carboxykinase, which is the main enzyme for regulation (Geetha et al., 2018; Lee et al., 2003). Interestingly other studies, Ong et al. (2013) showed chlorogenic acid has other functions as antidiabetic. Chlorogenic acid regulates glucose and lipid metabolism via the activation of AMPK and inhibited hepatic G6Pase expression and activity, which controlled glucose production. The potential of chlorogenic acid functions as a PPAR- $\gamma$ gene activator because it has functions to increase insulin sensitivity as a glucose controller in the blood, thereby reducing the risk of type 2 diabetes mellitus (T2DM).

\section{Conclusion}

Chlorogenic acid is one of the bioactive compounds found in coffee that are easily absorbed and has high permeability. This compound also has the potential as natural properties in anti-diabetes therapy by modulating the PPAR- $\gamma$ gene. This is concluded based on the results of protein-ligand interactions by producing 13 amino 
acid residues (GLN410, SER394, ASP396, GLY395, GLU407, LEUA401, LEU400, VAL403, LYS373, LYS438, LEU377, LYS434, and GLY437) which interacted with chlorogenic acid. We found hydrogen bond and Van der Waals bond to connect chlorogenic acid and amino acid residues.

\section{References}

Adriana, F. (2012). Coffee: Emerging Health Effects and Disease Prevention, First Edition. John Willey \& Sons, Inc and Institute of Food Technologists (USA) (1st ed.). Wiley-Blackwell Publishing Ltd.

Aleshin, S., Strokin, M., Sergeeva, M., \& Reiser, G. (2013). Peroxisome proliferatoractivated receptor (PPAR) $\beta / \delta$, a possible nexus of PPAR $\alpha$ - and PPAR $\gamma$-dependent molecular pathways in neurodegenerative diseases: Review and novel hypotheses. Neurochemistry International, 63(4), 322-330. https://doi.org/10.1016/j.neuint.2013.06.012

Bare, Y., Kuki, A. D., Rophi, A. H., \& Candrakirana, G. (2019). Prediksi Asam Kuinat Sebagai Anti-Inflamasi Terhadap COX-2 Secara Virtual Virtual Prediction of Quinic Acid as Anti-Inflammation of COX-2. Biota: Jurnal Ilmiah Ilmu-Ilmu Hayati, 4(3), 124-129. https://doi.org/10.24002/biota.v4i3.2516

Bare, Y., Marhendra, A., Sasase, T., \& Fatchiyah, F. (2018). Differential Expression of IL10 Gene and Protein in Target Tissues of Rattus Norvegicus Strain Wistar Model Type 2 Diabetes Mellitus (T2DM). Acta Informatica Medica, 26(2), 87-92. https://doi.org/10.5455/aim.2018.26.87-92

Bare, Y., Sari, D. R., Rachmad, Y. T., Tiring, S. S. N. D., Rophi, A. H., \& Nugraha, F. A. D. (2019). Prediction Potential Chlorogenic Acid As Inhibitor Ace (In Silico Study). Bioscience, 3(2), 197-203. https://doi.org/10.24036/0201932105856-0-00

Bare, Y., Sari, D. R. T., Rachmad, Y. T., Krisnamurti, G. C., \& Elizabeth, A. (2019). In Silico Insight the Prediction of Chlorogenic Acid in Coffee through Cyclooxygenase-2 (COX2) Interaction. Biogenesis: Jurnal Ilmiah Biologi, 7(2), 100-105. https://doi.org/10.24252/bio.v7i2.9847

Bermu'dez, V., Finol, F., Parra, N., Parra, M., Pe'rez, M., Peñaranda, L., Vı'lchez, D., Rojas, J., Arra'iz, N., \& Velasco, M. (2010). PPAR-g Agonists and Their Role in Type 2 Diabetes Mellitus Management. American Journal of Therapeutics, 17(3), 274283. https://doi.org/10.1097/MJT.0b013e3181c08081

Caprioli, G., Cortese, M., Maggi, F., Minnetti, C., Odello, L., Sagratini, G., \& Vittori, S. (2014). Quantification of caffeine, trigonelline and nicotinic acid in espresso coffee: The influence of espresso machines and coffee cultivars. International Journal of Food Sciences and Nutrition, 65(4), 465-469. https://doi.org/10.3109/09637486.2013.873890 
Chaudhury, A., Duvoor, C., Reddy Dendi, V. S., Kraleti, S., Chada, A., Ravilla, R., Marco, A., Shekhawat, N. S., Montales, M. T., Kuriakose, K., Sasapu, A., Beebe, A., Patil, N., Musham, C. K., Lohani, G. P., \& Mirza, W. (2017). Clinical Review of Anti-diabetic Drugs: Implications for Type 2 Diabetes Mellitus Management. Frontiers in Endocrinology, 8. https://doi.org/10.3389/fendo.2017.00006

Farah, A., \& dePaula Lima, J. (2019). Consumption of Chlorogenic Acids through Coffee and Health Implications. Beverages, 5(1), 11. https://doi.org/10.3390/ beverages 5010011

Farah, A., \& Donangelo, C. M. (2006). Phenolic compounds in coffee. Brazilian Journal of Plant Physiology, 18(1), 23-36. https://doi.org/10.1590/S167704202006000100003

Farhaty, N. (2016). Tinjauan Kimia Dan Aspek Farmakologi Senyawa Asam Klorogenat $\begin{array}{lllll}\text { Pada Biji Kopi: } & \text { Review. }\end{array}$ http://jurnal.unpad.ac.id/farmaka/article/view/10769

Geetha, B., Gunasekaran, V., \& Reddy, G. V. S. (2018). Thiazolidinedione Derivatives As Anti-diabetic Agents: A Short Review. International Research Journal Of Pharmacy, 9(2), 1-6. https://doi.org/10.7897/2230-8407.09217

Greenfield, J. R., \& Chisholm, D. J. (2004). Experimental and clinical pharmacology: Thiazolidinediones - mechanisms of action. Australian Prescriber, 27(3), 67-70. https://doi.org/10.18773/austprescr.2004.059

Hall, S., Desbrow, B., Anoopkumar-Dukie, S., Davey, A. K., Arora, D., McDermott, C., Schubert, M. M., Perkins, A. V., Kiefel, M. J., \& Grant, G. D. (2015). A review of the bioactivity of coffee, caffeine and key coffee constituents on inflammatory responses linked to depression. Food Research International, 76, 626-636. https://doi.org/10.1016/j.foodres.2015.07.027

Hannele, Y.-J. (2004). Thiazolidinediones. The New England Journal of Medicine, 13. https://doi.org/10.1056/NEJMra041001

Indonesian Bureau of Statistics. (2019, July 20). Produksi Kopi Menurut Kabupaten/Kota di Provinsi Nusa Tenggara Timur, 2004-2017. Produksi Kopi Menurut Kabupaten/Kota di Provinsi Nusa Tenggara Timur, 2004-2017. Produksi Kopi Menurut Kabupaten/Kota di Provinsi Nusa Tenggara Timur, 2004-2017

International Diabetes Federation. (2015). Diabetes Atlas (7th ed., Vol. 7). IDF.

Kesuma, D., Siswandono, S., Purwanto, B. T., \& Hardjono, S. (2018). Uji in silico Aktivitas Sitotoksik dan Toksisitas Senyawa Turunan N-(Benzoil)-N'- feniltiourea Sebagai Calon Obat Antikanker. JPSCR: Journal of Pharmaceutical Science and Clinical Research, 3(1), 01-11. https://doi.org/10.20961/jpscr.v3i1.16266 
Kreicbergs, V. (2011). Biologically Active Compounds In Roasted Coffee. Foodbalt, 6.

Kubota, N., Terauchi, Y., Kubota, T., Kumagai, H., Itoh, S., Satoh, H., Yano, W., Ogata, H., Tokuyama, K., Takamoto, I., Mineyama, T., Ishikawa, M., Moroi, M., Sugi, K., Yamauchi, T., Ueki, K., Tobe, K., Noda, T., Nagai, R., \& Kadowaki, T. (2006). Pioglitazone Ameliorates Insulin Resistance and Diabetes by Both Adiponectindependent and -independent Pathways. Journal of Biological Chemistry, 281(13), 8748-8755. https://doi.org/10.1074/jbc.M505649200

Laukalēja, I., \& Krūma, Z. (2018). Quality of specialty coffee: Balance between aroma, flavour and biologically active compound composition: review. 240-247. https://doi.org/10.22616/rrd.24.2018.038

Lee, C.-H., Olson, P., \& Evans, R. M. (2003). Minireview: Lipid Metabolism, Metabolic Diseases, and Peroxisome Proliferator-Activated Receptors. Endocrinology, 144(6), 2201-2207. https://doi.org/10.1210/en.2003-0288

Lipinski, C. A., Lombardo, F., Dominy, B. W., \& Feeney, F. J. (1997). Experimental and computational approaches to estimate solubility and permeability in drug discovery and development settings. Advanced Drug Delivery Reviews, 23, 3-25. https://doi.org/10.1016/S0169-409X(96)00423-1

Nuhu, A. A. (2014). Bioactive Micronutrients in Coffee: Recent Analytical Approaches for Characterization and Quantification. ISRN Nutrition, 2014, 1-13. https://doi.org/10.1155/2014/384230

Ong, K. W., Hsu, A., \& Tan, B. K. H. (2013). Anti-diabetic and anti-lipidemic effects of chlorogenic acid are mediated by ampk activation. Biochemical Pharmacology, 85(9), 1341-1351. https://doi.org/10.1016/j.bcp.2013.02.008

Santoso, B., Atmajaya, T. E., \& Tirtodiharjo, M. K. (2016). Kajian Docking Senyawa 4[(Z)-N-(4-hidroksifenil) carboksimidoil]-2- metoksifenol Sebagai Inhibitor Cox-2 Menggunakan Plants. (May).

Tiring, S. S. N. D., Bare, Y., Maulidi, A., Nugraha, F. A. D., \& S, M. (2019). Studi In Silico: Prediksi Potensi 6-Shogaol dalam Zingiber officinale sebagai Inhibitor JNK. Al Kimia, 07(02), 147-159. https://doi.org/10.24252/al-kimia.v7i2.10638

Tokarz, V. L., MacDonald, P. E., \& Klip, A. (2018). The cell biology of systemic insulin function. The Journal of Cell Biology, 217(7), 2273-2289. https://doi.org/10.1083/jcb.201802095

Tyagi, S., Sharma, S., Gupta, P., Saini, A., \& Kaushal, C. (2011). The peroxisome proliferator-activated receptor: A family of nuclear receptors role in various diseases. Journal of Advanced Pharmaceutical Technology \& Research, 2(4), 236240. https://doi.org/10.4103/2231-4040.90879 
Zanin, R. C., Corso, M. P., Kitzberger, C. S. G., Scholz, M. B. dos S., \& Benassi, M. de T. (2016). Good cup quality roasted coffees show wide variation in chlorogenic acids content. LWT, 74, 480-483. https://doi.org/10.1016/j.lwt.2016.08.012 